\title{
Efficacy of Bacteriocin Extracted from Lactobacillus acidophilus (LAK) against Bacillus cereus in cow raw milk
}

\author{
Abdul-Hadi A. Abd and Thikra M. Ali \\ Department of Veterinary Public Health, College of Veterinary Medicine, Baghdad University, \\ Iraq. \\ E-mail: thikramahmood@yahoo.com \\ Accepted: 23/2/2015 \\ Summary
}

Fifty seven out of ninety bovine milk samples were collected from different areas inside and nearby Baghdad which were positive for Bacillus cereus. The isolates were checked on chromogenic Bacillus cereus agar which was specific for detection of $B$. cereus colonies. The colony appearance, gram stain, spore stain and oxidase lipase monitol catalase tests were carried out to identify this bacterium. Bacteriocin extracted from Lactobacillus acidophilus was used as a tool to control the growth of undesirable B. cereus growth as spoilage and pathogenic bacteria as well as to keep the food more acceptable and safe to consumer. The results of this study showed that bacteriocin (LAK) had 8 a bactericidal effect against $B$. cereus in refrigeration and room temperatures at $\mathrm{pH} \mathrm{4,7}$ and 9, respectively. High potency of bacteriocin (LAK) was confirmed by minimum inhibitory concentration at 30, 60 and 120 minutes. It was found that the zone of inhibition of $B$. cereus by bacteriocin at $4{ }^{\circ} \mathrm{C}$ and $\mathrm{pH} 7$ was $26 \mathrm{~mm}$. The present study revealed that bacteriocin was highly effective against locally isolated B. cereus.

Keywords: Bacteriocin extract, Lactobacillus acidophilus, Bacillus cereus, Milk, Cow.

\section{Introduction}

Bacillus cereus was first isolated in 1887 from cowshed air by Frankland and Frankland (1). It may be the most common aerobic spore bearer in many types of soil and in sediments, dust, and plants (2). $B$. cereus is also frequently present in food production environments due to the adhesive nature of its endospores (3). This species has been isolated from a variety of foods, such as meat, eggs, spices, dairy, and rice products. The presence of $B$. cereus in pasteurized milk and other dairy products is a major concern of the dairy industry since contamination of milk by this organism can lead to both spoilage and safety problem (4). Its spore-forming and psychro-trophic properties assist $B$. cereus to grow and produce toxins in pasteurized milk at refrigerator temperature. Food-borne outbreaks and cases attributed to B. cereus in North America, Europe and Japan were ranged from $1 \%$ to $22 \%$ for outbreaks covering $0.733 \%$ of the cases. The Netherlands and Norway were reported to have the most extensive problem due to $B$. cereus. The threshold number of $B$. cereus is around $10^{6}$ colony forming units (CFU) per gram of food ingested (1 and 5). B. cereus has been known as a potential pathogen responsible for most of the food poisoning outbreaks (6).

Lactobacillus acidophilus strain and a member of the normal intestinal microflora is widely used in fermented dairy products and is of considerable industrial and medical interest because it has been reported to aid in the reduction of the levels of harmful bacteria and yeasts in the small intestine and to produce lactase, an enzyme which is important for the digestion of milk (7). Therefore L. acidophilus group of lactic acid bacteria $(\mathrm{LAB})$ is added as dietary adjuncts to commercial fermented milk products and the intake of these bacteria may have beneficial effects on human health (8). The production of bacteriocin occurred in log phase and was highest in the $\mathrm{pH}$ range of 5.5-6. Activity declined considerably when cell entered into death phase (9). The first bacteriocin to appear on both the European food additive list and the United States FDA list was intended for the use in the production of pasteurized processed cheese (10). The aims of the present study was to investigate the availability of $B$. cereus in raw milk samples collected randomly from different areas within and outside Baghdad locations and to evaluate the bactericidal potency of crude 
bacteriocin produced by L. acidophilus (LAK)

against the survival of B. cereus.

\section{Materials and Methods}

Ninety bovine raw milk samples were collected randomly at weekly intervals (10 samples a week) in sterile $100 \mathrm{ml}$ plastic bags from different regions of Baghdad city and its surrounding districts then transported to the laboratory in ice-cooled box. Brilliance B. cereus agar (Chromogenic agar) was one of the solid culture mediums that used for the isolation, identification and enumeration of $B$. cereus and the authors addressed that the new chromogenic media represent a good alternative to the conventional standard media (11). It was prepared according to the manufacturer instructions (Oxoid / UK). After exposure each milk sample to heat treatment at $80^{\circ} \mathrm{C}$ for 12 minutes plating was done within 3-6 hrs of arrival of the samples to the laboratory. Isolation of $\mathrm{B}$. cereus was carried out by spreading $0.1 \mathrm{ml}$ of $10-1$ and $10-2$ of milk samples on the Brilliance B. cereus agar (Chromogenic agar), and then incubated at 37 ${ }^{\circ} \mathrm{C}$ for 24 hours after the incubation period the colonies were counted in a Colony Counter (UK). The crude bacteriocin was obtained from the bacteriocin producing strains Lactobacillus acidophilus LAK which was grown in MRS broth under anaerobic condition at $37^{\circ} \mathrm{C}$ for 24 hours the supernatant fluid was separated from cells by centrifugation at $5000 \mathrm{rpm}$ for $30 \mathrm{~min}$. Late the supernatant was collected and $\mathrm{pH}$ was adjusted to 6.8- 7 with sterile in $\mathrm{NaOH}$ to exclude the effect of organic acids was filtered through a syringe filter with pore size of $0.45 \mu \mathrm{m}$, then heating for $10 \mathrm{~min}$ at $70^{\circ} \mathrm{C}$ to inactivate antibacterial peptides (protease) and to destroy cells and were stored at $4{ }^{\circ} \mathrm{C}$ in a refrigerator (12).

The antimicrobial activity of bacteriocin against B. cereus was determined using agar well diffusion assay. B. cereus was isolated and identified from raw milk samples after 24 hours of aerobic incubation at $37^{\circ} \mathrm{C}$ on chromogenic agar. Five colonies of $\mathrm{B}$. cereus were transferred to tube containing $5 \mathrm{ml}$ of sterile nutrient broth and was incubated at $37^{\circ} \mathrm{C}$ for $24 \mathrm{hr}$. one $\mathrm{ml}$ of cultured nutrient broth containing $B$. cereus counts of approximately lx $106 \mathrm{cfu} / \mathrm{ml}$ was transferred into a sterile Petri dish and then pour plated with Muller-Hinton agar and kept in the refrigerator for 2-3 hr. Five wells (6 in diameter) were made inside the soft agar seeded with $B$. cereus $50 \mu 1$ of crude bacteriocin were added into each well. The plate then was incubated overnight at $37^{\circ} \mathrm{C}$. After the incubation, the diameter of the clear inhibition zone was measured using the standard ruler and the presence of $2 \mathrm{~mm}$ or more clear zone of inhibition around the wells was regarded as a positive results.

The levels of resistance to natural antimicrobial agent such as bacteriocin was determined by the dilution method proposed by (13) with slight modifications. Serial dilutions of bacteriocin were made in a liquid media which was inoculated with a standardized number of B. cereus 106 and incubated aerobically at $37^{\circ} \mathrm{C}$ for overnight. The minimal inhibitory concentration (MIC) was considered as the MIC at which the turbidity due to the bacterial growth that measured by .spectrophotometer was not observed and this value was recorded by (13). Growth (biomass) was measured by determining its turbidity in terms of optical density (OD) at $540 \mathrm{~nm}$ by spectrophotometer according to the manufacturer instructions (Optima sp 300, Japan). Effect of bacteriocin on B. cereus in a liquid medium was determined by deducing the dead or growth inhibition of indicator organism at various dilutions of crude bacteriocin which were added to indicator organism $6.3 \mathrm{cfu} / \mathrm{ml}$ which inoculated in sterile nutrient broth and incubatdd overnight at $37^{\circ} \mathrm{C}$. Indicator cells without bacteriocin were used as (14). Statistical analysis was done according to simple student t-test and Two-way ANOVAs (15).

\section{Results and Discussion}

Isolation of Bacillus Cereus from bovine raw milk samples were collected from different districts inside and surround Baghdad. In the current study, ninety raw milk samples were collected, a total of 10 samples from each district. The prevalence of B. cereus in raw milk samples from the above mentioned different locations inside and surround Baghdad are shown in (Table, 1). 
Fifty seven out of ninety $(63.33 \%)$ raw milk samples had positive results for presence of B. cereus while the maximum count of $\mathrm{B}$. cereus was $760.44 \mathrm{cfu} / \mathrm{ml}$ and the mean value was $1.768 \pm 0.430 \mathrm{cfu} / \mathrm{ml}$. Four out of ten $(40 \%)$ milk samples were positive which were collected from the College of Agriculture Farm and Al-Rashdia were positive with the maximum counts of $300,700 \mathrm{cfu} / \mathrm{ml}$ and mean values of $0.980 \pm 0.390$ and $1.069 \pm 0.429$ $\mathrm{cfu} / \mathrm{ml}$, respectively. Howevers six of milk samples were positive $(60 \%)$ in the College of Veterinary Medicine Farm and Al-Tarmia with the maximum counts $900,800 \mathrm{cfu} / \mathrm{ml}$ and mean values of $1.713 \pm 0.437 \mathrm{cfu} / \mathrm{ml}$ and $1.587 \pm 0.405 \mathrm{cfu} / \mathrm{ml}$ respectively. The outcomes of Al-Radhwania east and AlBakria farms, eight out of ten $(80 \%)$ milk samples were positive with the maximum ranges of $1530 \mathrm{cfu} / \mathrm{ml}$ and $730 \mathrm{cfu} / \mathrm{ml}$ and means values of $2.344 \pm 0.070 \mathrm{cfu} / \mathrm{ml}$ and $2.285 \pm 0.292 \mathrm{cfu} / \mathrm{ml}$ respectively. While in AlRadhwania west farm five milk samples were positive (50\%) with Maximum count of 900 $\mathrm{cfu} / \mathrm{ml}$ and mean values $1.482 \pm 0.472 \mathrm{cfu} / \mathrm{ml}$. Nine of milk samples were positive $(90 \%)$ in Al-Sowera with a maximum counts 544 $\mathrm{cfu} / \mathrm{ml}$ and a mean value $2.374 \pm 0.316 \mathrm{cfu} / \mathrm{ml}$. These results revealed different variations in the counts of $B$. cereus isolates. These differences in the numbers were either due to impact of the sanitation system applied in these locations or belonging to the animal management regime which may include grooming and the type of food and water offered to these animals as well as the environment surrounding these locations (15). All notes of milk samples obtained from different location inside and surround Baghdad were similar to the findings (Table, 1). The results obtained from the Farm of Agriculture College, Al- Radhwania west and Al-Rashdia had revealed significant $(\mathrm{P}<0.05)$ versus those of the Farm of Veterinary College, Al-Radhwania east, Al-Bakria and Al-Sowera. While the observations of AbuGraib, and Al-Tarmia farms were not significant with those of all farms mentioned earlier. These findings of the present study were in agreement with those of other scientific literature (16 and 17) who isolated B. cereus from raw, pasteurized milk and other dairy products. The highest mean values of $\mathrm{B}$. cereus isolates were obtained from the AlSowera, Al-Radhwania east and Al-Bakria which were $2.374 \pm 0.316,2.344 \pm 0.070$ and $2.285 \pm 0.292 \mathrm{cfu} / \mathrm{ml}$, respectively.

As compared with the other locations, the investigation of $B$. cereus isolates indicated that such cows produce low milk quality in the areas which need farther attention for better cleaning and management however, the udder hygiene represented by milk characters should be routinely checked for the presence of somatic cell counts preferably every 6 month to identify the infecting animals with subclinical mastitis spicily those with $B$. cereus (18).

Furthermore, the highest incidence of $B$. cereus was observed in the location of AlSowera having 9 (90\%) which were infected with B. cereus. Also, Al-Bakria and AlRadhwania east locations had high infection with B. cereus with eight (80\%) while moderate infection was noted in Abu-Graib area which was seven $(70 \%)$. The other locations had low incidence with B. cereus such as Veterinary College Farm and AlTarmia location having six infected $(60 \%)$ samples. While Al-Radhwania west location had lower count as compared with other locations reflecting five (50\%) samples positive out of ten, with exception of the College of Agriculture Farm and Al-Rashdia which had the lowest incidence with B. cereus which were four $(40 \%)$ out of ten positive samples. The results of the present study were in discrepancy with the findings recorded by others (19 and 20) who attributed the discrepancy to the difference in the breed of cows, of the environment and to the technique of isolation of B. cereus. The same outcomes to the present results were found in the research performed by (21). It is worthy to demonstrate that $B$. cereus spores in raw milk represents the major source of $B$. cereus. Bacillus had been isolated from $58 \%$ of raw milk samples tested and $94 \%$ of the positive milk samples was stored at $6^{\circ} \mathrm{C}$ for 14 days. 
Table, 1: The prevalence of $B$. cereus in cow raw milk samples from different locations inside and surround Baghdad.

\begin{tabular}{|c|c|c|c|c|c|}
\hline \multirow[t]{2}{*}{ Location } & \multirow{2}{*}{$\begin{array}{l}\text { No. of } \\
\text { samples }\end{array}$} & \multirow{2}{*}{$\begin{array}{c}\text { No. of }(+) \mathrm{Ve} \\
\text { samples }\end{array}$} & \multirow{2}{*}{$\begin{array}{c}\text { Isolation } \\
\%\end{array}$} & \multicolumn{2}{|c|}{ Counting of $\boldsymbol{B}$. cereus } \\
\hline & & & & Maximum cfu/ml & Mean cfu/ml \\
\hline \multirow{2}{*}{ Agriculture) College Farm } & 10 & 4 & $40 \% \mathrm{H}$ & 300 & $0.980 \pm 0.390 B$ \\
\hline & 10 & 6 & $60 \% \mathrm{D}$ & 900 & $1.713 \pm 0.437 \mathrm{~A}$ \\
\hline Veterinary College Farm & 10 & 7 & $70 \% \mathrm{C}$ & 440 & $2.081 \pm 0.268 \mathrm{AB}$ \\
\hline Abu-Graib & 10 & 8 & $80 \% B$ & 730 & $2.344 \pm 0.070 \mathrm{~A}$ \\
\hline \multirow{2}{*}{ Al-Radh east } & 10 & 5 & $50 \% \mathbf{E}$ & 900 & $1.482 \pm 0.472 \mathrm{~B}$ \\
\hline & 10 & 8 & $80 \%$ B & 1530 & $2.285 \pm 0.292 \mathrm{~A}$ \\
\hline Al-Radh west & 10 & 9 & $90 \% \mathrm{~A}$ & 544 & $2.374 \pm 0.316 \mathrm{~A}$ \\
\hline \multirow{3}{*}{$\begin{array}{l}\text { Al-Bakria } \\
\text { Al-Sowera }\end{array}$} & 10 & 4 & $40 \% \mathrm{H}$ & 700 & $1.069 \pm 0.429 B$ \\
\hline & 10 & 6 & $60 \% \mathrm{D}$ & 800 & $1.587 \pm 0.405 \mathrm{AB}$ \\
\hline & 90 & 57 & $63.33 \%$ & 760.44 & $1.768 \pm 0.430$ \\
\hline
\end{tabular}

There were capital letters in the (Table, 1$)$ indicated that the similar letter were not significant while the different were significant $(\mathbf{P}<0.05)$.

Bacteriocin activity bioassay against $B$. cereus by well diffusion method: Inhibitory zone measurement was done on solid media by pouring method including $1 \mathrm{ml}$ of $10^{6} \mathrm{cfu} / \mathrm{ml}$, with mean inhibition zone of $26 \mathrm{~mm}$. Inhibitory zone was $24 \mathrm{~mm}$ when it was carried out in 0.5 $\mathrm{ml}$ of $10^{6} \mathrm{cfu} / \mathrm{ml}$, in case of $2 \mathrm{ml}$ of $6 \mathrm{cfu} / \mathrm{ml}$, the mean of inhibitory zone were $22 \mathrm{~mm}$. These results indicated that the potency of bacteriocin against $B$. cereus was effective to kill B. cereus (Fig. 1 and 2). The potency of bacteriocin was measured in $E$. coli as a Gram negative bacteria. The result of $12 \mathrm{~mm}$ and $6 \mathrm{~mm}$ was recorded as a maximum inhibitory zones, however, the readings of inhibitory zone of bacteriocin against $B$. cereus had effective potency comparing those of $E$. coli. The results in this study were similar to those reported by (22). The potency of bacteriocin against numbers of $\mathrm{B}$. cereus was measured after incubation at $37^{\circ} \mathrm{C}$ for $0,30,60$ and $120 \mathrm{~min}$. The number of $B$. cereus counts began at more than $6.3 \mathrm{cfu} / \mathrm{ml}$. Their number after $30 \mathrm{~min}$. incubation at $37^{\circ} \mathrm{C}$ with bacteriocin was low to $5.9 \mathrm{cfu} / \mathrm{ml}$, and after an hour of incubation. Consequently, the reduction was down to $5.6 \mathrm{cfu} / \mathrm{ml}$. The count numbers after two hours of incubation reached less than $5.3 \mathrm{cfu} / \mathrm{ml}$. These outcomes showed that the bacteriocin were highly effective against $B$. cereus counts. The bacteriocin in this study was observed to have broad spectrum inhibitory activity against B. cereus (Fig. $3)$.

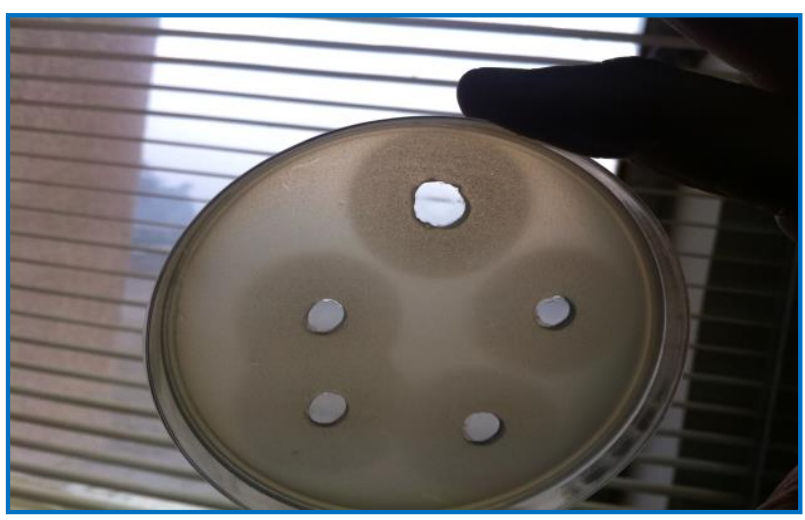

Figure, 1: Inhibition Zone of Bacteiocin in $B$. cereus on chromogenic agar.

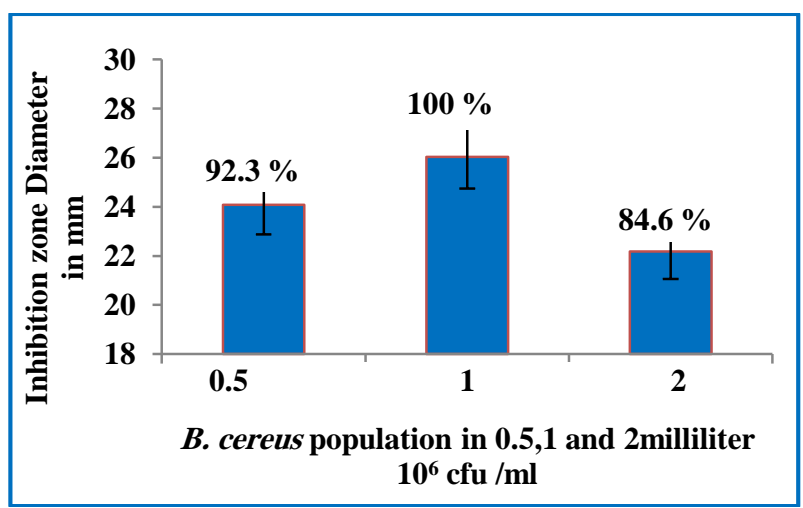

Figure, 2: Effect of Bacteriocin activities $B$. cereus count in Bacteriocin activities.

These findings were in agreement with (23 and 24) who reported that production of bacteriocin is highly affected by the many factors such as the species of microorganisms, ingredients and $\mathrm{pH}$ of medium, incubation temperature and time. The zone of inhibition by bacteriocin for B. cereus count at $\mathrm{pH} 4$ was $14 \mathrm{~mm}(53 \%)$ as a mean reading while in $\mathrm{pH} 9$ the mean reading was $13 \mathrm{~mm}(50 \%)$. In $\mathrm{pH} 7$ the width of the zone of the inhibition ranged $30 \mathrm{~mm}$ and $26 \mathrm{~mm}$ as a mean (100\%) (Fig. 4). 


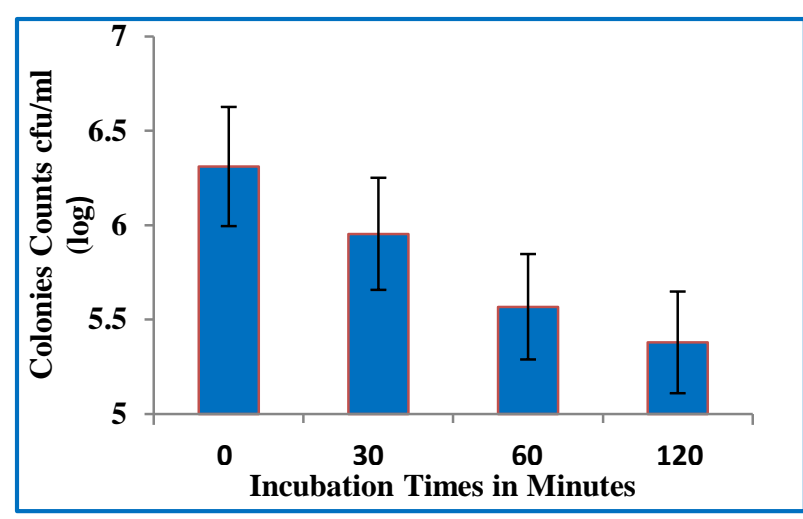

Figure, 3: Effectiveness of crude bacteriocin on bioavailability of $B$. cereus in nutrient broth kept at refrigeration temperature for 120 minutes.

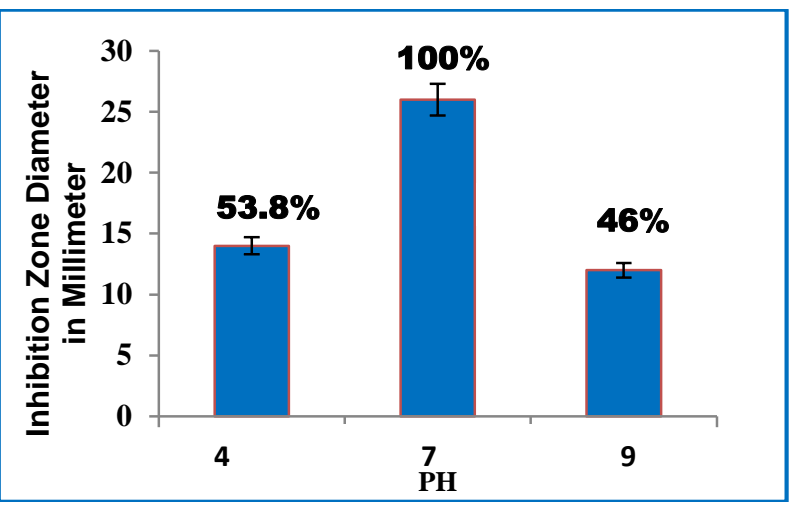

Figure, 4: Potency of crude bacteiocin of $L$. acidophilus LAK at different $P H$ values against $B$. cereus.

These results relating to inhibition zone indicated that the $\mathrm{pH} 7$ was the optimum $\mathrm{pH}$ for perfect bactericidal activity of bacteriocin. It was found that both alkaline pH 9 and acidic $\mathrm{pH} 4$ possessed decreased effect of the bactericidal activity of bacteriocin (Fig. 4). Similar findings were reported by (25) who noticed that the bactericidal activity at the $\mathrm{pH} 9$ was high against Bacillus subtilis $(12 \mathrm{~mm})$ and the concentration employed was 100111. It was evident that the bactericidal effect of bacteriocin was highly dependent on the $\mathrm{pH}$. Notably an increase in the level of $\mathrm{pH}$ above 9 showed a reduction in the inhibitory activity. The levels of $\mathrm{pH}$ were between 4 to 9 which was the optimum $\mathrm{pH}$ for favorable inhibitory activity of bacteriocin from Lactobacillus spp. against a wide spectrum of various pathogenic organisms.

The minimum inhibitory concentration of bacteriocin results were shown in the readings of optical density at concentration $1 / 1$ were $1.011 \pm 0.0011$ before incubation and 1.020 \pm 0.0015 after incubation at $37^{\circ} \mathrm{C}$ for $24 \mathrm{hrs}$. Optical density at $1 / 2$ was $1.076 \pm 0.0052$ before incubation and after the reading of optical density at $1 / 4$ was $1.118 \pm 0.0021$ and after incubation was $1.124 \pm 0.00348$ incubation the optical density reading was $1.092 \pm 0.003$. In $1 / 8$ bacteriocin dilution the optical density (OD) of B. cereus growth was $1.130 \pm 0.0038$ before incubation and $1.157 \pm 0.00176$ after incubation. The reading of OD before incubation at dilution $1 / 16$ was $1.144 \pm 0.0017$ and after incubation was $1.647 \pm 0.038$. The control reading of OD before and incubation was $1.661 \pm 0.038$ and $1.991 \pm 0.0095$, respectively (Table, 2 ).

Table, 2: Turbid metric Assay for the Minimum Inhibitory Concentration test in (log) by using Spectrophotometer.

\begin{tabular}{|c|c|c|c|c|c|c|}
\hline $\begin{array}{l}\text { Tube } \\
\text { Number }\end{array}$ & Dilutions of Bacteriocin & $\begin{array}{l}\text { O.D. } 540 \mathrm{~nm} \text { Before incu } \\
\text { (mean of replicati }\end{array}$ & ation & $\begin{array}{l}\text { O.D. } 540 \mathrm{~mm} \text { After in } \\
\text { overnight (mean of re }\end{array}$ & $\begin{array}{l}\text { Ibation } \\
\text { ications) }\end{array}$ & $\begin{array}{l}\text { Growth detection } \\
\text { By streaking }\end{array}$ \\
\hline 1 & $\begin{array}{l}1 / 1 \\
1 / 2\end{array}$ & $\begin{array}{l}1.011 \pm 0.0011 \\
1.076 \pm 0.0052\end{array}$ & $\begin{array}{l}\mathbf{D} \\
\mathbf{D}\end{array}$ & $\begin{array}{l}1.020 \pm 0.0015 \\
1.092 \pm 0.003\end{array}$ & $\begin{array}{l}\mathbf{E} \\
\mathbf{E}\end{array}$ & $\begin{array}{l}\text { (-ve) growth } \\
\text { (-ve) growth }\end{array}$ \\
\hline 3 & $1 / 4$ & $1.118 \pm 0.0021$ & $\mathbf{C}$ & $1.124 \pm 0.00348$ & D & (-ye) growth \\
\hline 4 & $1 / 8$ & $1.130 \pm 0.0038$ & $\mathbf{C}$ & $1.157 \pm 0.00176$ & $\mathbf{C}$ & (-ye) growth \\
\hline 5 & $1 / 16$ & $1.144 \pm 0.0017$ & B & $1.647 \pm 0.038$ & $\mathbf{B}$ & (+ve) growth \\
\hline 6 & $\begin{array}{l}\text { Nutrient broth and } \text { B. cereus } \\
\text { suspension (as control) }\end{array}$ & $1.661 \pm 0.038$ & $\mathbf{A}$ & $1.991 \pm 0.0095$ & $\mathbf{A}$ & (+ve) growth \\
\hline
\end{tabular}

Different capital letters in a column revealed significant differences $(P<0.05)$ between dilutions factor of bacteriocin. Horizontal different capital letters revealed significant differences $(P<0.05)$. O D = Optical density, - Ve $=$ Negative growth, + Ve $=$ Positive growth

The OD readings before and after incubation were significantly different at $(\mathrm{P}<0.05)$ in bacteriocin dilution within $1 / 1$, $1 / 2$ and $1 / 4,1 / 8$. The readings of $O D$ in bacteriocin dilution $1 / 16$ before and after incubation were significantly different at $(\mathrm{P}<0.05)$ with all the fore-mentioned dilutions. The bacteriocin extracted from L. acidophilus plays an important role in controlling the total bacterial count, aerobic- 
spore formers and psychrotrophic bacterial counts in pasteurized milk. Moreover, it can extend shelf-life of pastured milk up to 12 days especially at concentration 320 and 160 $\mathrm{IU} / \mathrm{ml}$ (26) On the other hand, some contaminants like aerobic spore formers and psychrotrophic microorganisms may multiply in food during its storage, affecting its safety and quality. Such damage may involve pasteurized milk leading to spoilage problems as bitter cream, off-flavors or sweet curdling. Other harm reflecting the decrease shelf-life and substantial economic losses of milk products (27). Bacteriocins are used as tool to control the growth of undesirable microbial growth including spoilage and pathogenic bacteria and to keep the food quality more acceptable and palatable to the consumer (28).

\section{References}

1. Griffiths, M. W. and Schraft, H. (2002). Bacillus cereus food poisoning In: Food borne Diseases, Cliver, DO and Riemann, HP (Eds) Academic press, London. Pp: 261270.

2. Arnesen, L. P. S.; Fogerlund, A. and Granum, P. E. (2008). From soil to gut: Bacillu cereus and its food poisoning toxins. FEMS Microbial. Rev., (32): 579-606.

3. Ribeiro, N. F. F.; Heath, C. H.; Kierath, J.; Rea, S.; Duncan-Smith, M. and Wood, F. M. (2009). Burn wounds infected by contaminated water: case reports, review of the literature, and recommendations for treatment. [Epub ahead of print]

4. Christiansson, A.; Naidu, A.; Nilsson, S.; Wadstrih, T. and Pettersson, H. E. (1989). Toxin production by Bacillus cereus dairy isolates in milk at low temperature. Appt. Environ. Microbio1., 155: 2595-2600.

5. Lee, S.; Chung, H.; Shin, J.; Dougherty, R. H. and Kang, D. (2006). Survival and growth of foodborne pathogens during cooking and storage of oriental rice cakes. J. Food Protect., (69): 3037-3042.

6. Kramer, J. M. and Gilbert, R. J. (1989). Bacillus cereus and other Bacillus species, In M. P. Doyle (ed.), Food-borne Bacterial Pathogens. Marcel Dekker, Inc., New York, N.Y., Pp: 21-70.
7. Deraz, S.; Karlsson, N. E.; Khalil, A. A. and Mattiasson, B. (2007). Mode of action of acidocin D20079, a bacteriocin produced by the potential probioticstrain, Lactobacillus acidophilus DSM 20079. J. Ind. Microbial. Biotechnol., (34): 373-379.

8. Kawai,Y.; Ishii, Y.; Uemura, K.; Kitazawa, H.; Saito, T. and Itoh, T. (2001). Lactobacillus reuteri LA 6 and Lactobacillus gasseri LA 39 isolated from faeces of the same human infant produce identical cyclicmbacteriocin. Food Microb., (18): 407-415.

9. Dave, R. I. and Shah, N. P. (1997). Effect of cysteine on the viability of yoghurt and probiotic bacteria in yogurt made with commercial starter cultures. Int. Dairy J., (7): 537-54.

10. Forouhandeh, H.; Zununi-Vahed, S.; Hejazi, M. S.; Nahaei, M. R. and Akbari Dibavar, M. (2010). Isolation and phenotypic characterization of Lactobacillus species from various dairy products. Curr. Res. Bacteriol., 3(2): 84-88.

11. Fricker, M.; Reissbrodt, R. and EhlingSchulz, M. (2008). Evaluation of standard and net' chromogenic selective plating media for isolation and identification of Bacillus cereus. Int. J. Food Microbiol., (12): 27-34.

12. Kim, O. S. H. and Worobo, R. W. (2000). Characterization and Purification of a Bacteriocin Produced by a Potential Probiotic Culture, Lactobacillus acidophilus 30SC. J. Dairy Sci., (83): 2747-2752.

13. Davidson, P. M. and Parish, M. E. (1989). Methods for testing the efficacy of food antimicrobials. Food Technol., (43): 148155.

14. Choi, O. K.; Kim, Y.S.; Cho, G. S. and Sung, C. K. (2002). Screening for antimicrobial activity from Korean plants. Kor. J. Food Nut., (15): 300-306.

15. ALAllaf, M. A. H.; Al-Rawi, A. M. M. and Al-Mola, A. T. (2010). Inhibitory effect of Lactic Acid Bacteria isolated from minced beef meat on some Pathogeni bacteria. Environmental and Pollution Control Research Center, Mosul University, Mosul, Iraq.

16. Torkar, K. G. and Mozina, S. S. (2000). Differentiation of Bacillus cereus Isolates from Milk and Milk Products with 
Biochemical, Immunological, AP-PCR and PCR-RFLP Methods. Institute of Dairying, Zoo technical Dept., Biotechnical Faculty, University of Ljubljana, Groblje 3, SI-1230 Dom' ale, Slovenia.

17. Olawale, A. K. and Akintobi, O. A. (2011). Antibiotic Resistant Bacillus cereus in Some Selected Foods in Osun State, Nigeria. Report and Opinion. 3(1): http://www.sciencepub.net/report 21.

18. Helgason, E.; Okstad, O. A.; Caugant, D. A.; Johansen, H. A.; Fouet, A.; Mock, M.; Hegna, I. and Kolsto, A. B. (2000) Bacillus anthracis, Bacillus cereus, and Bacillus thuringiensis - one species on the basis of genetic evidence. Appl. Environ. Microb., (66): 2627-2630.

19. Hameed, K. G. A.; Sender, G. and KorwinKossakowska, A. (2008). An association of BoLA alleles DRB3.2*16 and DRB3.2*23 with occurrence of mastitis caused by different bacterial species in two herds of dairy cows. Anim. Sci. Papers and Reports. 26 (1): 37-48.

20. Te Giffel, M. C.; Beumer, R. R.; Klijn, N.; Wagendorp, A. and Rombouts, F. M. (1997). Discrimination between Bacillus cereus and Bacillus thuringiensis using specific DNA probes based on variable regions of 16S rRNA. FEMS Microbiology Letters, 146 (1): 47-51.

21. Jensen, G. B.; Hansen, B. M.; Ellenberg, J. and Mahillon. J. (2003). The hidden lifestyles of Bacillus cereus and relatives. Environ. Microbiol., (5): 631-640.
22. Kalalou, I.; Faid, M. and Ahami, A. T. (2004). Extending shelf life of fresh minced camel meat at ambient temperature by Lactobacillus dlbrueckii subsp. Delbrueckii. 7: 1-6.

23. Ibrahim, E. M. A. and Elbarbary, H. A. (2012). Effect of Bacteriocin extracted from Lactobacillus acidophilus on the Shelflife of Pasteurized Milk. J. Am. Sci., 8(2): 620-626.

24. Ouwehand, A. C. and Vesterlund, S. (2004). Antimicrobial components from lactic acid bacteria. Lactic Acid Bacteria Microbiological and Functional Aspects. New York: Marcel Dekker Inc.

25. Ben, C. P.; Beula, A. and Nirmala Devi, S. (2012). Production and partial purification of Lactocin produced from Lactobacillus lactis and its Bactericidal activity against Food spoiling bacteria. ISCA J. Biol. Sci., 1(3): 49-53.

26. Reij, M. W. D.; Aantrekker, E. D. and ILSI Europe. (2004). Risk Analysis in Microbiology task force recontamination as a source of pathogens in processed foods. Int. J. Food Microb., (9): 1-11.

27. Oh, S.; Kim, S. H. and Worobo, R.W. (2000). Characterization and purification of a Bacteriocin produced by a potential probiotic culture, Lactobacillus acidophilus 30SC. J. Dairy Sci., (83): 2747-2752.

28. Deegan, L. H.; Cotter, P. D.; Hill, C. and Ross, P. (2006). Bacteriocins: Biological tools for biopreservation and shelf-life extension. Int. Dairy J., (16): 1058-1071.

\section{فعالية الباكتيريوسين المستخرج من ملبنة اسيدوفيلوس (لاك) ضد العصيات الشمعية المكونة للابواغ في مليب الابقّار الخام عبدالهادي عباس عبد و ذكرى محمود علي الإني

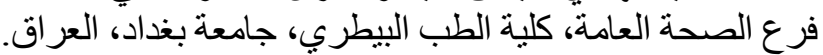 \\ E-mail: thikramahmood@yahoo.com \\ الخلاصة}

جمعت عينات حليب البقر السبعة والخمسين الإيجابية للعصيات الثمعية المكونة للأبواغ من أصل تسعين عينة من مناطق مختلفة من

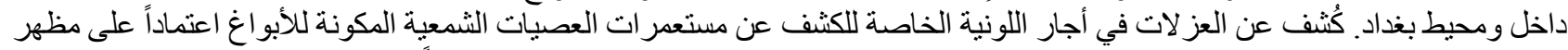

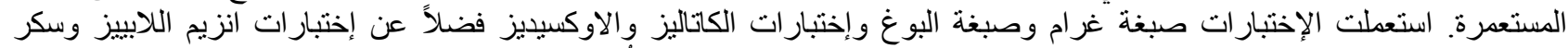

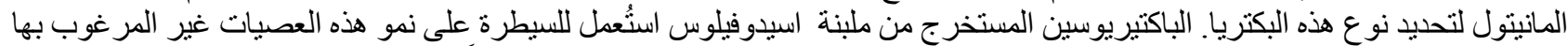

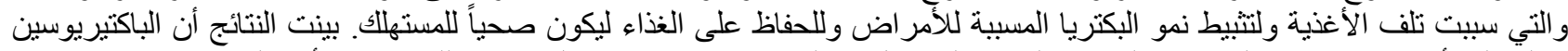

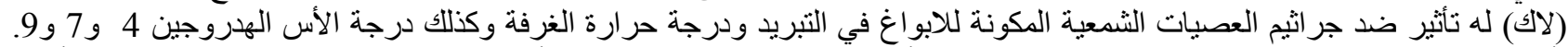

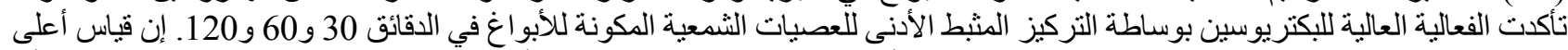

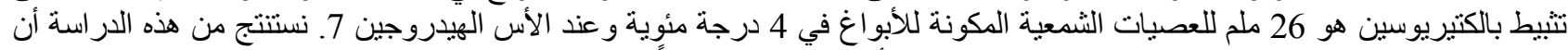

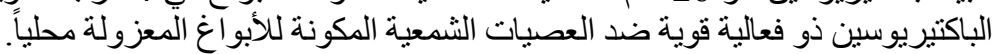
الكلمات المفتاحية: الباكتيريوسين المستخرج، ملبنة اسيدوفيلوس، العضيدئ العيات الثمعية، الحليب، الابقار. 